\title{
Survey Pelaksanaan Pembelajaran Sepakbola dalam Pendidikan Jasmani Secara Daring pada Masa Covid 19 di SMK Sentra Medika Cikarang Utara
}

\author{
Bagas Firgiawan Ruhiyat ${ }^{1}$, Sutarjo, Febi Kurniawan. \\ ${ }^{1}$ Universitas Singaperbangsa Karawang,bagasfirgiawan9@gmail.com \\ ${ }^{2}$ Universitas Singaperbangsa Karawang.febi.kurniawan@fkip.unsika.ac.id \\ ${ }^{3}$ Universitas Singaperbangsa Karawang \\ * Corresponding Author. E-mail: ${ }^{1}$ bagasfirgiawan9@gmail.com
}

Receive: 10/08/2021

Accepted: 20/09/2021

Published: 11/10/2021

\begin{abstract}
Abstrak
Survei Pelaksanaan Pembelajaran Sepakbola Dalam Pendidikan Jasmani Secara Daring Pada Masa Pandemi COVID- 19 Di SMK Sentra Medika Cikarang Utara. Tujuan, mengetahui seberapa tinggi tingkat Pelaksanaan Pembelajaran Sepakbola Dalam Pendidikan Jasmani. Konsep, Pendidikan jasmani pada hakikatnya adalah proses pendidikan yang memanfaatkan aktivitas fisik untuk menghasilkan perubahan holistic dalam kualitas individu, baik fisik, mental, serta emosional, menurut Warsito dan Abdullah (2018:3). Metode survei angket dengan instrumen dalam bentuk kuesioner. Subyek berjumlah 41 siswa. Teknik analisis data dalam penelitian Ini menggunakan analisis deskriptif kuantitatif yang diberikan dalam bentuk persentase. Hasil dalam penelitian menunjukkan bahwa ditemukan Pelaksanaan Pembelajaran Sepakbola Dalam Pendidikan Jasmani kategori "sangat kurang baik" sebanyak 7,32\% (3 siswa), "kurang baik" adalah sebanyak 21,95\% (9 siswa), "cukup baik" adalah sebanyak 48,78\% (20 siswa), "baik"adalah sebanyak 12,20\% (5 siswa), dan "sangat baik" sebanyak 9,76\% (4 siswa). Berdasarkan skor rata-rata(mean), yaitu 23,12 termasuk dalam kategori cukup dengan frekuensi 20 siswa. Jenis penelitian ini menggunakan pendekatan kuantitatif deskriptif dengan populasi \& sampel sekolah SMK Sentra Medika Cikarang Utara Tahun Ajaran 2021/2022 yang berjumlah 41 orangdengan rincian 26 siswa kelas XI prodi/jurusan Keperawatan dan 15 siswa kelas XI prodi/jurusan Farmasi.
\end{abstract}

Kata Kunci: Pembelajaran, Sepakbola, Pandemi Covid

\begin{abstract}
Survey on the Implementation of Football Learning in Physical Education Online During the COVID-19 Pandemic At SMK Sentra Medika Cikarang Utara. The purpose is to find out how high the level of Implementation of Football Learning in Physical Education is. Conceptually, physical education is essentially an educational process that utilizes physical activity to produce holistic changes in individual qualities, both physically, mentally, and emotionally, according to Warsito and Abdullah (2018: 3). Questionnaire survey method with the instrument in the form of a questionnaire. Subjects amounted to 41 students. The data analysis technique in this study used quantitative descriptive analysis which was given in percentage form. The results in the study showed that it was found that the implementation of soccer learning in physical education was in the "very poor" category as many as 7.32\% (3 students), "poor" was 21.95\% (9 students), "good enough" was 48 ,78\% (20 students), "good" is $12.20 \%$ (5 students), and "very good" is 9.76\% (4 students). Based on the average score (mean), which is 23.12, it is included in the sufficient category with a frequency of 20 students. This type of research uses a descriptive quantitative approach with a population \& school sample of North Cikarang Sentra Medika Vocational School in the 2021/2022 academic year, totaling 41 people with details of 26 students in class XI in Nursing study program and 15 students in class XI in Pharmacy study program.
\end{abstract}

Keywords: Learning, Football, Covid Pandemic 


\section{Pendahuluan}

Pendidikan merupakan suatu proses yang mencakup tiga dimensi, individu, masyarakat atau komunitas nasional dari individu tersebut, dan seluruh kandungan realitas, baik material maupun spiritual yang memainkan peranan dalam menentukan sifat, nasib, bentuk manusia maupun masyarakat . Ki Hajar Dewantara dalam mengartikan pendidikan sebagai daya upaya untuk memajukan budi pekerti, pikiran serta jasmani anak, agar dapat memajukan kesempurnaan hidup yaitu hidup dan menghidupkan anak yang selaras dengan alam dan masyarakatnya. Pendidikan merupakan salah satu faktor utama dalam pelaksanaan pembangunan nasional, terutama dalam mempersiapkan sumberdaya manusia yang tangguh .Pendidikan merupakan kebutuhan sepanjang hayat. Setiap manusia membutuhkan pendidikan, sampai kapanpun dan dimanapun berada. Pendidikan sangat penting artinya, sebab tanpa pendidikan manusia akan sulit berkembang dan bahkan akan terbelakang.

Menurut Husdarta pada proses pembelajaran PJOK ditekankan bahwa pengembangan individu secara menyeluruh, dalam arti pengembangan yang mencakup perkembangan fisik mental intelektual dan perkembangan sosial. Sejak surat keputusan dari Menteri Pendidikan dan Kebudayaan terbit mengenai upaya pencegahan dan penyebaran virus corona atau Covid-19, semua kegiatan pembelajaran secara langsung mulai diliburkan sementara waktu. Pembelajaran daring dilakukan sebagai pilihan stategis dalam memutus penyembaran wabah covid19.

Pandemi Covid 19 atau masuknya virus Corona ke Indonesia telah mengubah proses pembelajaran sekolah di hampir sebagian besar wilayah Indonesia menjadi Pendidikan Jarak Jauh, belajar dari rumah, atau School from Home .Sebelum memulai pembelajaran pendidikan jasmani, seorang pendidik harus memiliki Rancangan Pelaksanaan Pembelajaran yang mengacu pada kurikulum 2013 . Didalam RPP tersebut terdapat sebuah indikator mengenai pembelajaran bola besar seperti sepak bola, bola basket, bola voli.

Pada saat ini pemerintah Indonesia menerapkan protokol kesehatan COVID-19 yang mengharuskan masyarakat berdiam diri di rumah masing-masing termasuk kegiatan belajar mengajar di sekolah yang di alihkan di rumah, untuk mencegah penyebaran virus COVID-19.

Oleh sebab itu pelaksaan kegiatan pembelajaran sepakbola harus di lakukan secara daring dan wajib dilaksanakan agar proses transformasi ilmu pengetahuan kepada peserta didik tidak terhambat, hal itu di lakukan guna memutus mata rantai penyebaran virus COVID-19. Pembelajaran daring merupakan pembelajaran yang menggunakan jaringan internet dengan aksesibilitas, konektivitas, fleksibilitas, dan kemampuan untuk memunculkan berbagai jenis interaksi pembelajaran . Kuntarto, E dalam mengatakan Pembelajaran daring adalah pembelajaran yang mampu mempertemukan antara mahasiswa dan dosen untuk melaksanakan interaksi pembelajaran dengan bantuan internet. Guru dan peserta didik, bahkan orang tua dipaksa untuk beradaptasi secara cepat dengan metode daring, di tengah situasi yang sedang terjadi saat ini, metode daring adalah solusi yang paling tepat untuk dilakukan.

\section{Metode}

Penelitian ini merupakan penelitian kuantitatif deskriptif untuk mengetahui gambaran pelaksanaan pembelajaran sepakbola secara daring pada mata pelajaran Pendidikan Jasmani Olahraga dan Kesehatan (PJOK). Subjek penelitian adalah siswa kelas XI di SMK Sentra Medika Cikarang Utara Tahun Ajaran 2021/2022 yang berjumlah 41 orang dengan rincian 26 siswa kelas XI prodi/jurusan Keperawatan dan 15 siswa kelas XI prodi/jurusan Farmasi. Pengukuran gejala yang diamati berdasarkan fakta dari responden itu sendiri.

Populasi dalam penelitian ini adalah siswa kelas XI di SMK Sentra Medika Cikarang Utara Tahun Ajaran 2021/2022 yang berjumlah 41 orang dengan rincian 26 siswa kelas XI prodi/jurusan Keperawatan dan 15 siswa kelas XI prodi/jurusan Farmasi.

Sampel yang diambil dalam penelitian ini, dari seluruh populasi siswa kelas XI SMK Sentra Medika Cikarang yang berjumlah 41 siswa. Penelitian ini menggunakan sampling jenuh yang dimana sampling jenuh adalah teknik penentuan sampel bila semua anggota populasi digunakan sebagai sampel. 
Jurnal Edumaspul, 5 (2), Year 2021 - 614

penelitian ini penyusun menggunakan angket bersifat tertutup (berstruktur), hal ini didasarkan pada pengetahuan dan pengalaman responden yang berbeda-beda, selain itu untuk menghindari informasi yang lebih meluas. Penyusun menggunakan kuesioner tertutup sehingga dengan demikian responden tinggal memilih beberapa alternatif jawaban yang tersedia. Penyusun menggunakan kuesioner dengan skala Guttman.

Dalam penelitian ini pengumpulan data yang digunakan yaitu menggunakan kuisioner atau angket yang merupakan teknik pengumpulan data dengan cara memberi seperangkat pertanyaan atau pernyataan tertulis kepada responden untuk dijawabnya.

Teknik analisis data yang digunakan dalam penelitian ini yaitu dengan analisis data deskriptif kuantitatif. (Sugiyono, 2017: 7) berpendapat bahwa, metode ini sebagai metode ilmiah/scientific karena telah memenuhi kaidah-kaidah ilmiah yaitu konkrit/empiris, obyektif, terukur, rasional, dan sistematis.

\section{Hasil}

Hasil penelitian ini dimaksudkan untuk menggambarkan data yaitu pelaksanaan pembelajaran dalam pendidikan jasmani olahraga dan kesehatan di masa pandemi COVID-19 pada SMK Sentra Medika Cikarang Utara.

Tabel 1. Penilaian pelaksanaan pembelajaran sepakbola dalam pendidikan jasmani selama pandemi covid-19 di SMK Sentra Medika Cikarang Utara.

\begin{tabular}{|c|c|c|c|c|}
\hline No & Interval & Kategori & Frekuensi & Persentase \\
\hline 1 & $12,84<X$ & Sangat Baik & 4 & $9.76 \%$ \\
\hline 2 & $11,01<\mathrm{X} \leq 12,84$ & Baik & 5 & $12.20 \%$ \\
\hline 3 & $9,18<X \leq 11,01$ & Cukup Baik & 20 & $48.78 \%$ \\
\hline 4 & $7,36<X \leq 9,18$ & Kurang Baik & 9 & $21.95 \%$ \\
\hline 5 & $X \leq 7,36$ & $\begin{array}{c}\text { Sangat Kurang } \\
\text { Baik }\end{array}$ & 3 & $7.32 \%$ \\
\hline \multicolumn{3}{|c|}{ Jumlah } & 41 & $100 \%$ \\
\hline
\end{tabular}

Berdasarkan dari tabel di atas, dapat dipaparkan bahwa pelaksanaan pembelajaran sepakbola dalam pendidikan jasmani olahraga dan kesehatan di masa pandemi COVID-19 pada SMK
Sentra Medika Cikarang Utara berdasarkan faktor persiapan pembelajaran yaitu, sangat baik sebanyak 4 siswa atau sebesar 10\%, dalam kategori baik sebanyak 5 siswa atau sebesar $12 \%$, dalam kategori cukup baik sebanyak 20 siswa atau sebesar 49\%, dalam kategori kurang baik sebanyak 9 siswa atau sebesar 22\%, sedangkan dalam kategori sangat kurang baik sebanyak 3 siswa atau sebesar $7 \%$. Misalnya, dapat dilihat dari gambar 1.

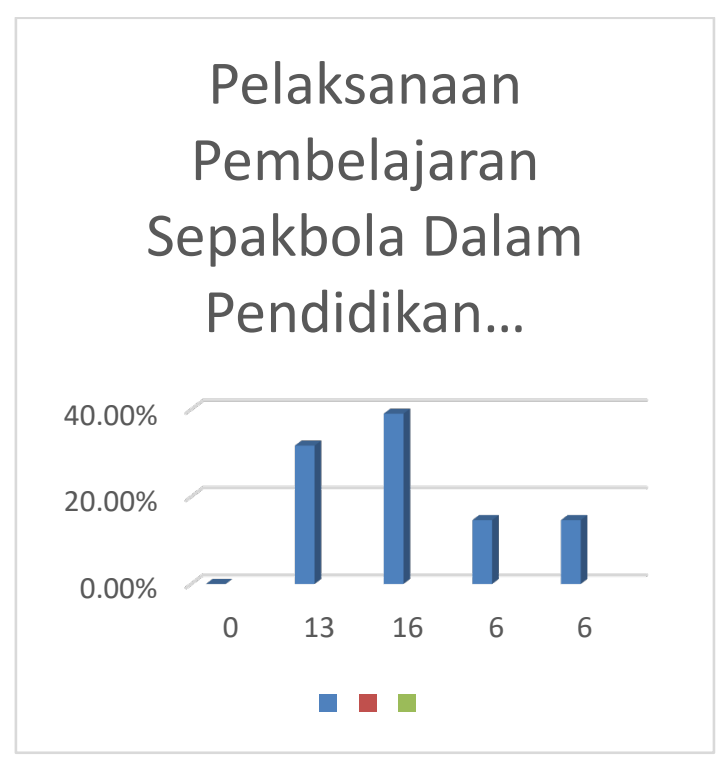

Gambar.1 Diagram Pelaksanaan Pembelajaran Sepakbola Dalam Pendidikan Jasmani Secara Daring Pada Saat Pandemi Covid-19 di SMK Sentra Medika Cikarang Utara.

1. Faktor Persiapan Pembelajaran Sepakbola Dalam Pendidikan Jasmani Secara Daring Pada Saat Pandemi Covid-19 di SMK Sentra Medika Cikarang Utara.

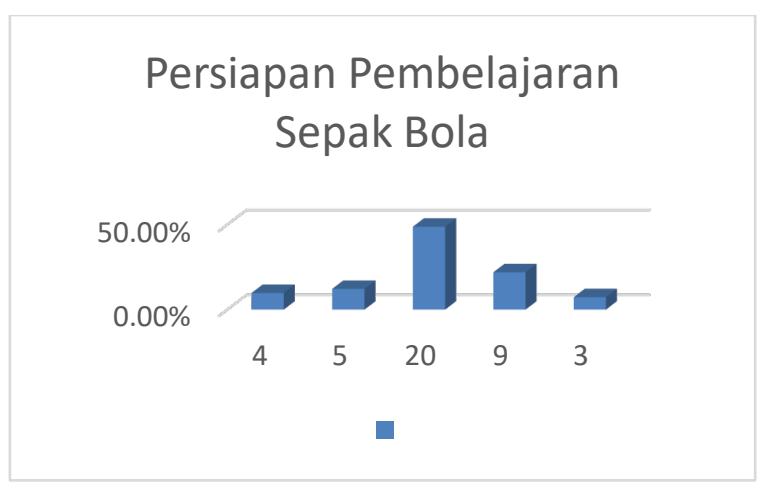


Gambar 2. Diagram Batang Persiapan Pembelajaran Sepak Bola Dalam Pendidikan Jasmani Secara Daring Pada Saat Pandemi Covid-19 di SMK Sentra Medika Cikarang Utara.

Berdasarkan hasil analisis pada gambar 2 diatas menunjukan tingkat persiapan pembelajaran sepak bola dalam pendidikan jasmani secara daring pada saat pandemi Covid-19. Berdasarkan faktor persiapan pembelajaran yaitu, sangat baik sebanyak 4 siswa atau sebesar 10\%, dalam kategori baik sebanyak 5 siswa atau sebesar 12\%, dalam kategori cukup baik sebanyak 20 siswa atau sebesar 49\%, dalam kategori kurang baik sebanyak 9 siswa atau sebesar 22\%, sedangkan dalam kategori sangat kurang baik sebanyak 3 siswa atau sebesar $7 \%$.

2. Faktor Pelaksanaan Pembelajaran

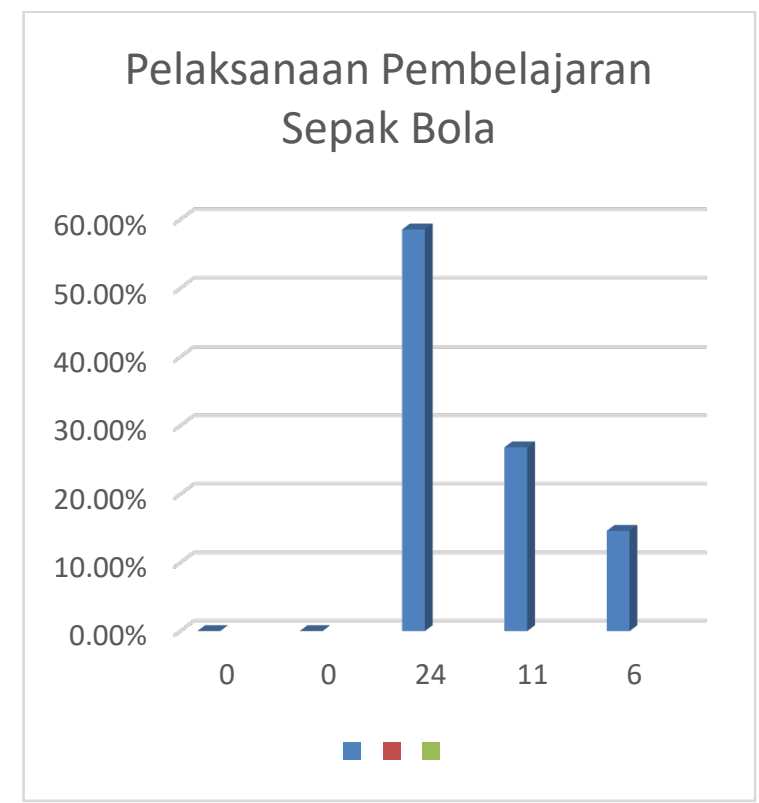

Gambar 3. Diagram Batang Pelaksanaan Pembelajaran Sepak Bola Dalam Pendidikan Jasmani Secara Daring Pada Saat Pandemi Covid-19 di SMK

Sentra Medika Cikarang Utara.

Berdasarkan hasil analisis pada gambar 3 diatas menunjukan tingkat pelaksanaan pembelajaran sepak bola dalam pendidikan jasmani secara daring pada saat pandemi Covid19. berdasarkan faktor pelaksanaan pembelajaran yaitu, sangat baik sebanyak 0 siswa atau sebesar $0 \%$, dalam kategori baik sebanyak 0 siswa atau sebesar $0 \%$, dalam kategori cukup baik sebanyak 24 siswa atau sebesar 59\%, dalam kategori kurang baik sebanyak 11 siswa atau sebesar $27 \%$, sedangkan dalam kategori sangat kurang baik sebanyak 6 siswa atau sebesar $15 \%$.

3. Faktor Evaluasi Pembelajaran SepakBola

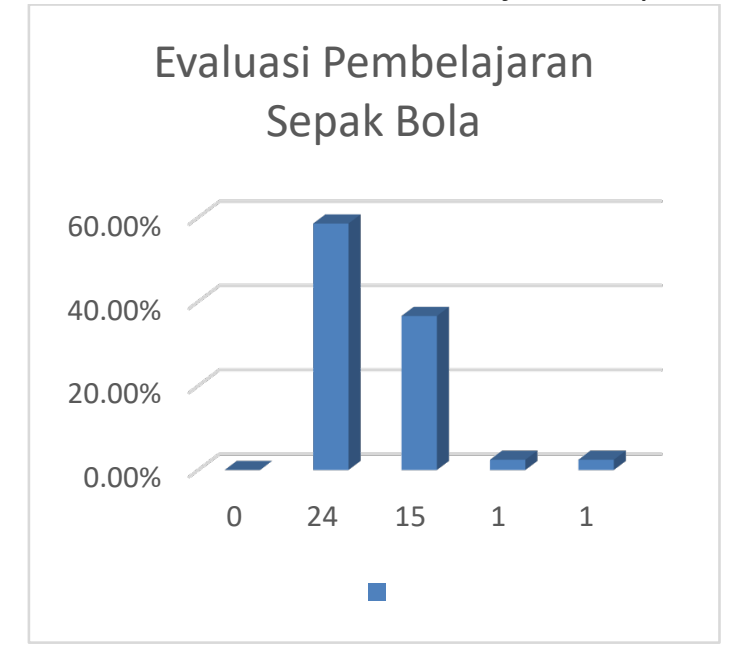

Gambar 4. Diagram Batang Evaluasi Pembelajaran Sepak Bola Dalam Pendidikan Jasmani Secara Daring Pada Saat Pandemi Covid-19 di SMK

Sentra Medika Cikarang Utara.

Berdasarkan hasil analisis gambar 4 di atas menunjukan tingkat evaluasi pembelajaran sepak bola. Berdasarkan faktor evaluasi pembelajaran yaitu, sangat baik sebanyak 0 siswa atau sebesar $0 \%$, dalam kategori baik sebanyak 24 siswa atau sebesar 59\%, dalam kategori cukup baik sebanyak 15 siswa atau sebesar $37 \%$, dalam kategori kurang baik sebanyak 1 siswa atau sebesar $2 \%$, sedangkan dalam kategori sangat kurang baik sebanyak 1 siswa atau sebesar $2 \%$

4. Indikator Sarana Pembelajaran Sepak Bola

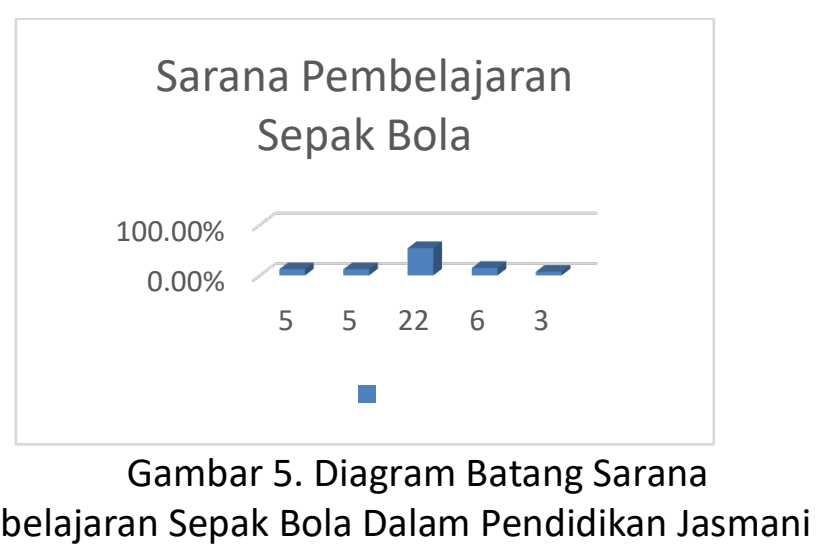


Jurnal Edumaspul, 5 (2), Year 2021 - 616

Secara Daring Pada Saat Pandemi Covid-19 di SMK Sentra Medika Cikarang Utara.

Berdasarkan hasil analisis gambar 5 di atas menunjukan tingkat sarana pembelajaran sepak bola. Berdasarkan faktor persiapan pembelajaran dalam indikator sarana pembelajaran yaitu, sangat baik sebanyak 5 siswa atau sebesar $12 \%$, dalam kategori baik sebanyak 5 siswa atau sebesar $12 \%$, dalam kategori cukup baik sebanyak 22 siswa atau sebesar 54\%, dalam kategori kurang baik sebanyak 6 siswa atau sebesar 15\%, sedangkan dalam kategori sangat kurang baik sebanyak 3 siswa atau sebesar $7 \%$.

5. Indikator Kompetensi Pembelajaran Daring

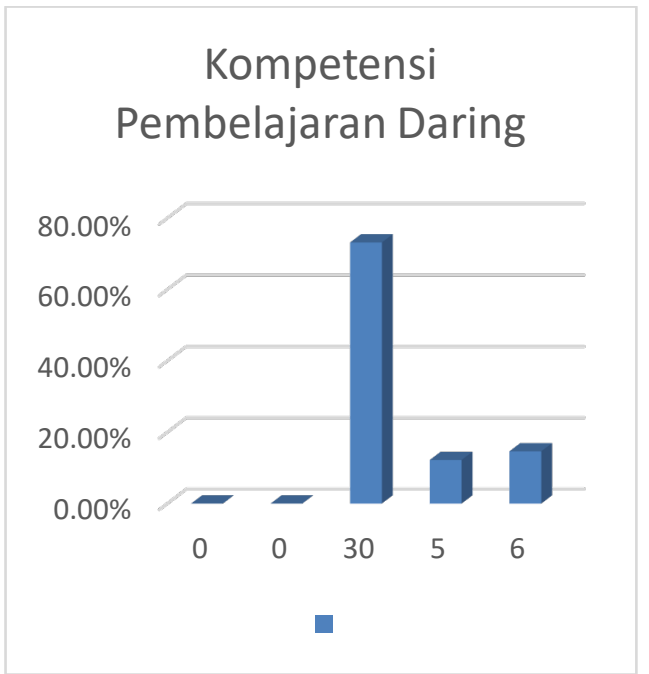

Gambar 6. Diagram Batang Kompetensi

Pembelajaran Sepak Bola Dalam Pendidikan Jasmani Secara Daring Pada Saat Pandemi Covid-19 di SMK Sentra Medika Cikarang Utara.

Berdasarkan hasil analisis gambar 6 di atas menunjukan tingkat kompetensi pembelajaran daring sepak bola. Berdasarkan faktor persiapan pembelajaran dalam indikator kompetensi pembelajaran daring yaitu, sangat baik sebanyak 0 siswa atau sebesar $0 \%$, dalam kategori baik sebanyak 0 siswa atau sebesar $0 \%$, dalam kategori cukup baik

7. Indikator Pembelajaran Praktek Sepak Bola sebanyak 30 siswa atau sebesar $73 \%$, dalam kategori kurang baik sebanyak 5 siswa atau sebesar $12 \%$, sedangkan dalam kategori sangat kurang baik sebanyak 6 siswa atau sebesar $15 \%$.

6. Indikator Pembelajaran Teori Sepak Bola

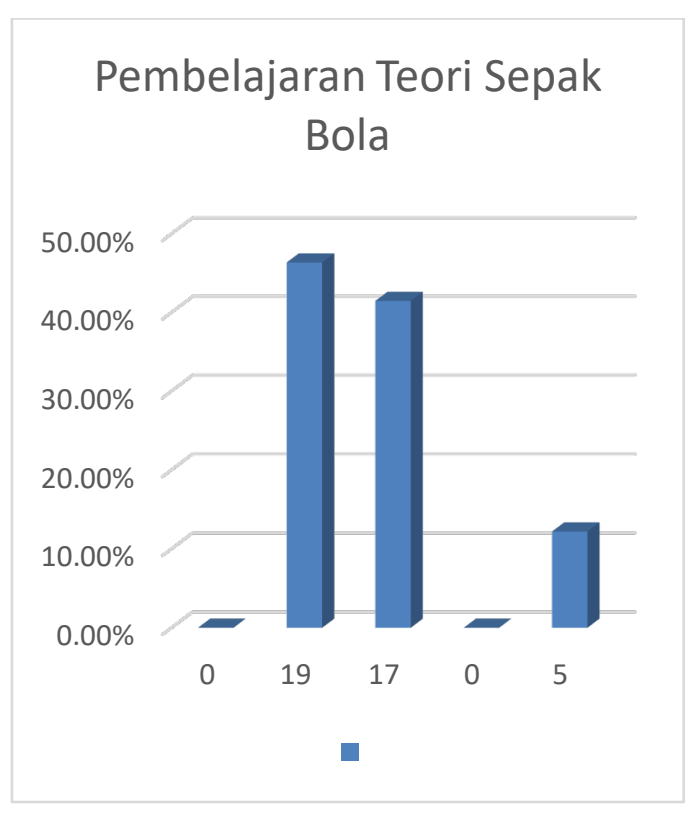

Gambar 7. Diagram Batang Pembelajaran Teori Sepak Bola Dalam Pendidikan Jasmani Secara Daring Pada Saat Pandemi Covid-19 di SMK Sentra Medika Cikarang Utara.

Berdasarkan hasil analisis gambar 7 di atas menunjukan tingkat pembelajaran teori sepak bola. Berdasarkan faktor pelaksaaan pembelajaran dalam indikator pembelajaran teori yaitu, sangat baik sebanyak 0 siswa atau sebesar $0 \%$, dalam kategori baik sebanyak 19 siswa atau sebesar 46\%, dalam kategori cukup baik sebanyak 17 siswa atau sebesar 41\%, dalam kategori kurang baik sebanyak 0 siswa atau sebesar $0 \%$, sedangkan dalam kategori sangat kurang baik sebanyak 5 siswa atau sebesar $12 \%$. 
Jurnal Edumaspul, 5 (2), Year 2021 - 617

(Bagas Firgiawan Ruhiyat ${ }^{1}$, Sutarjo, Febi Kurniawan)

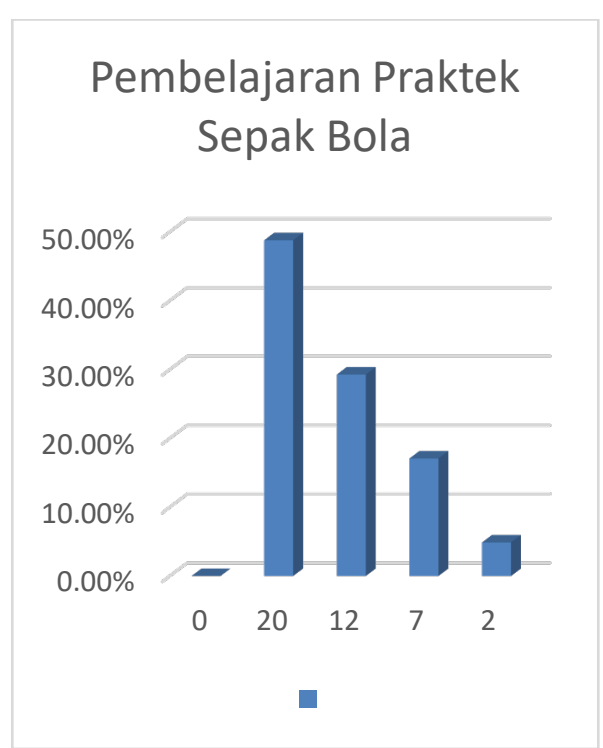

Gambar 8. Diagram Batang Pembelajaran Praktek Sepak Bola Dalam Pendidikan Jasmani Secara Daring Pada Saat Pandemi Covid-19 di

SMK Sentra Medika Cikarang Utara.

Berdasarkan hasil analisis gambar 8 di atas menunjukan tingkat pembelajaran peraktek sepak bola. Berdasarkan faktor persiapan pembelajaran dalam indikator pembelajaran praktek yaitu, sangat baik sebanyak 0 siswa atau sebesar $0 \%$, dalam kategori baik sebanyak 20 siswa atau sebesar $49 \%$, dalam kategori cukup baik sebanyak 12 siswa atau sebesar $29 \%$, dalam kategori kurang baik sebanyak 7 siswa atau sebesar $17 \%$, sedangkan dalam kategori sangat kurang baik sebanyak 2 siswa atau sebesar $5 \%$.

8. Indikator Penyelesaian Tugas.

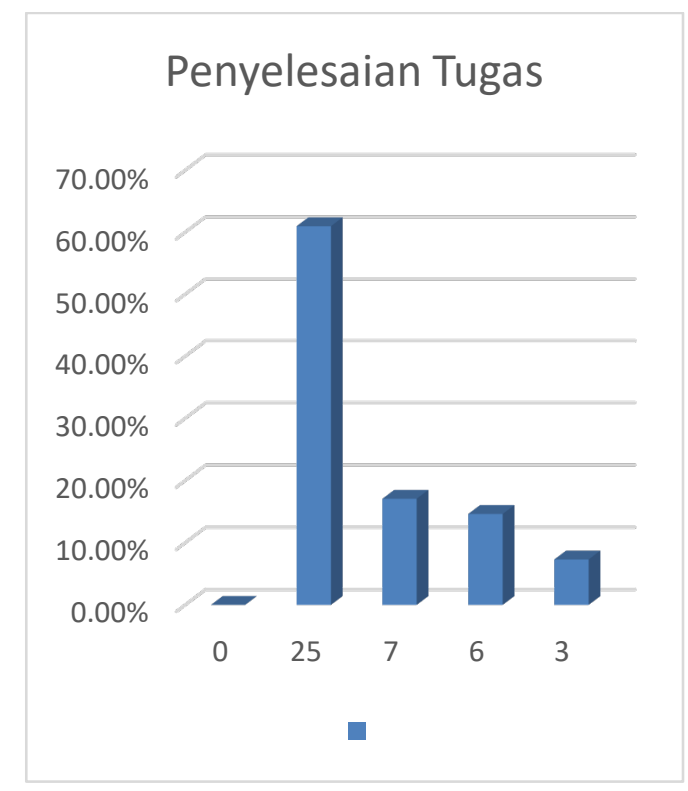

Gambar 9. Diagram Batang Pembelajaran Penyelesaian Tugas Sepak Bola Dalam Pendidikan Jasmani Secara Daring Pada Saat Pandemi Covid-19 di SMK Sentra Medika Cikarang Utara.

Berdasarkan hasil analisis gambar 9 di atas menunjukan tingkat pembelajaran penyelesaian tugas sepak bola. Berdasarkan faktor evaluasi pembelajaran dalam indikator penyelesaian tugas yaitu, sangat baik sebanyak 0 siswa atau sebesar $0 \%$, dalam kategori baik sebanyak 25 siswa atau sebesar $61 \%$, dalam kategori cukup baik sebanyak 7 siswa atau sebesar $17 \%$, dalam kategori kurang baik sebanyak 6 siswa atau sebesar 15\%, sedangkan dalam kategori sangat kurang baik sebanyak 3 siswa atau sebesar $7 \%$.

9. Indikator Pelaksanaan Ujian.

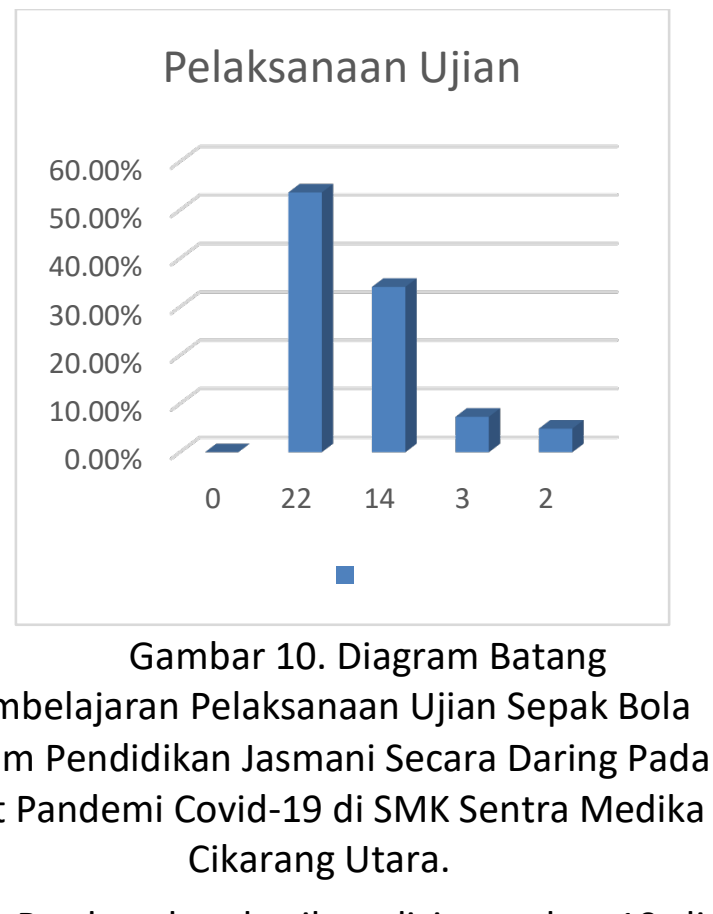

Berdasarkan hasil analisis gambar $10 \mathrm{di}$ atas menunjukan tingkat pembelajaran pelaksanaan ujian sepak bola. Berdasarkan factor evaluasi pembelajaran dalam indikator pelaksanaan ujian yaitu, sangat baik sebanyak 0 siswa atau sebesar $0 \%$, dalam kategori baik sebanyak 22 siswa atau sebesar 54\%, dalam kategori cukup baik sebanyak 14 siswa atau sebesar 34\%, dalam kategori kurang baik 
Jurnal Edumaspul, 5 (2), Year 2021 - 618

(Bagas Firgiawan Ruhiyat ${ }^{1}$, Sutarjo, Febi Kurniawan)

sebanyak 0 siswa atau sebesar $0 \%$, sedangkan dalam kategori sangat kurang baik sebanyak 5 siswa atau sebesar $12 \%$.

\section{PEMBAHASAN}

Dari hasil penelitian tersebut diketahui Pembelajaran pendidikan jasmani dalam situasi pandemi COVID-19 di SMK Sentra Medika Cikarang Utara yang menyatakan pada kategori "cukup baik" dengan persentase 39.02\% dengan frekuensi 16 Siswa. Dengan hasil katagori cukup baik menggambarkan bahwa proses pelaksanaan pembelajaran yang dilaksanakan di SMK Sentra Medika Cikarang Utara mata pelajaran sepakbola pendidikan jasmani sudah berjalan dengan cukup baik. Kategori baik ini di lihat berdasarkan Persiapan Pembelajaran, Pelaksanaan Pembelajaran, Evaluasi Pembelajaran.

Faktor Persiapan Pembelajaran. diketahui yang menyatakan pada kategori "cukup baik" dengan persentase $48.78 \%$ dengan jumlah frekuensi 20 siswa, dalam faktor persiapan pembelajaran terdapat indikator Sarana Pembelajaran. diketahui yang menyatakan pada kategori "cukup baik" dengan persentase $53.66 \%$ dengan frekuensi 22 siswa. Sedangkan indikator Kompetensi Pembelajaran Daring. diketahui yang menyatakan pada kategori "cukup baik" dengan persentase $73.17 \%$ dengan frekuensi 30 siswa.

Faktor Pelaksanaan Pembelajaran. diketahui yang menyatakan pada kategori "cukup baik" dengan persentase $58.54 \%$ dengan jumlah frekuensi 24 siswa, dalam faktor pelaksanaan pembelajaran terdapat indikator Pembelajaran Teori diketahui yang menyatakan pada kategori "cukup baik" dengan persentase $41.46 \%$ dengan frekuensi 17 siswa. Sedangkan indikator Kompetensi Pembelajaran Praktek diketahui yang menyatakan pada kategori "cukup baik" dengan persentase $29.27 \%$ dengan frekuensi 12 siswa

Faktor Evaluasi Pembelajaraan. diketahui yang menyatakan pada kategori "cukup baik" dengan persentase $36.59 \%$ dengan frekuensi 15 siswa. Dalam faktor evaluasi pembelajaran terdapat indikator Penyelesaian Tugas pada kategori "cukup baik" dengan persentase $17.07 \%$ dengan frekuensi 7 siswa dan Indikator Pelaksanaan Ujian. diketahui yang menyatakan pada kategori "cukup baik" dengan persentase $34.15 \%$ dengan frekuensi 14 siswa.

Dari ketiga faktor tersebut dengan banyaknya indikator yang berkatagori cukup baik menyimpulkan bahwa proses pelaksanaan pembelajaran sepakbola yang dilaksanakan di SMK Sentra Medika Cikarang Utara mata pelajaran sepakbola pendidikan jasmani sudah berjalan dengan cukup baik.

\section{KESIMPULAN}

Berdasarkan hasil analisis data pelaksanaan pembelajaran sepakbola dalam pembelajaran pendidikan jasmani olahraga secara daring di masa pandemi COVID- 19 pada SMK Sentra Medika Cikarang Utara berada pada kategori "sangat kurang baik" sebanyak 7,32\%, "kurang baik" sebanyak 21,95\%, "cukup baik" sebanyak 48,78\%, "baik" sebanyak $12,20 \%$, dan "sangat baik" sebanyak 9,76\%. Berdasarkan nilai rata-rata, yaitu $39,02 \%$ berada pada kategori cukup baik. Dengan demikian dapat diambil kesimpulan, bahwa pelaksanaan pembelajaran sepakbola dalam pembelajaran pendidikan jasmani olahraga secara daring di masa pandemi COVID- 19 pada SMK Sentra Medika Cikarang Utara berada pada kategori cukup baik.

\section{DAFTAR PUSTAKA}

Azhuri, I. R., Purbangkara, T., \& Nasution, N. S. (2021). Physical Education Learning Motivation Survey for Extraordinary School Students All Karawang Regency. Jurnal Literasi Olahraga, 2(2), 96-103.

Iskandar, A. D. (2020). Survey Pembelajaran Pendidikan Jasmani Dalam Situasi Covid Di SMP Negeri Se Kecamatan Purwakarta. Karawang.

Junaedi, A., \& Wisnu, H. (2015). SURVEI TINGKAT KEMAJUAN PENDIDIKAN JASMANI, OLAHRAGA, DAN KESEHATAN DI SMA, SMK, DAN MA NEGERI SEKABUPATEN GRESIK. 03, 834-842. 
Kresnapati, P., \& Setiawan, D. A. (2020). Analisis perkuliahan daring mahasiswa PJKR Universitas PGRI Semarang sebagai dampak pandemi covid 19. 1(1), 25-32.

Lanziotti, V. S., De Souza, D. C., \& Marques, E. T. A. (2020). EFEKTIVITAS PEMBELAJARAN JARAK JAUH DENGAN DARING SELAMA PANDEMI COVID-19 MATA PELAJARAN PENDIDIKAN JASMANI OLAHRAGA DAN KESEHATAN (PJOK) Oleh. Pediatric Critical Care Medicine, 1022-1023. https://doi.org/10.1097/PCC.000000000 0002513

Lestari, Eka Karunia dan Yudhanegara, M. R. (2017). Penelitian pendidikan matematika. Refika Adhitama.

Muhammad Sidik, N., Kurniawan, F., \& Effendi, R. (2021). Pengaruh Latihan Sepakbola Empat Gawang Terhadap Kemampuan Passing Stopping Sepakbola Ekstrakurikuler di SMP Islam Karawang. Jurnal Literasi Olahraga, 2(1), 60-67. https://doi.org/10.35706/jlo.v2i1.4434

Nur, M., Pradipta, G. D., \& Maliki, O. (2020). Efektivitas Pembelajaran Daring Mata Pelajaran Pjok Siswa Kelas Ix Di Mtsn 2 Semarang Selama Pandemi Covid-19. Seminar 108-125.

http://conference.upgris.ac.id/index.php /snk/article/view/1139

Nurul Raodatun Hasanah, I Putu Panca Adi, \& I Gede Suwiwa. (2021). Survey Pelaksaan Pembelajaran Pjok Secara Daring Pada Masa Pandemi Covid-19. Jurnal Kejaora (Kesehatan Jasmani Dan Olah Raga), 6(1), 189-196.

https://doi.org/10.36526/kejaora.v6i1.12 95

Rachman, A. (2019). Survei Tingkat Kemampuan Teknik Dasar Dalam Permainan Sepakbola Pada Siswa Kelas X Sman 1 Sinjai.

Sihanita, Y. K., \& Syam, A. R. (2020). KORELASI HASIL BELAJAR PENGETAHUAN DENGAN KETERAMPILAN SHOOTING MATERI SEPAKBOLA PADA MASA PANDEMI COVID-19 Yudis Korin Sihanita *, Abdul Rachman Syam Tuasikal.
Sudijono, A. (2012). Pengantar statistika. Pt. Rajagrafindo Persada. Sugiyono. (2017). Metode Penelitian Kuantitatif, Kualitatif, dan R\&D. Alfabeta, CV.

Wijayanto, A., Yunis, S., Ari, B., Kurniawan, W., Rahadian, A., Amiq, F., Ika, A., Joan, N., Andrianto, R., \& Baun, A. (n.d.). eBook $B$ Strategi Pembelajaran PJKR selama Covid19.

\section{Profil Penulis}

Nama :Bagas Firgiawan Ruhiyat Tempat, Tgl Lahir: $\quad$ Bekasi, 21 Januari 1998

Jenis Kelamin: Laki-Laki

Agama: Islam

Kewarganegaraan : Indonesia

Status : Lajang

Alamat Sekarang : Jln Tanjung

Raya Blok D no 359 Perumahan

Margahayu 